\title{
Hydrological and erosional response of a small catchment in Sicily
}

\author{
Feliciana Licciardello $^{1 *}$, Salvatore Barbagallo ${ }^{1}$, Francesc Gallart ${ }^{2}$ \\ ${ }^{1}$ University of Catania, Department of Agriculture, Food and Environment, Catania, Italy. \\ ${ }^{2}$ Institute of Environmental Assessment and Water Research (IDAEA-CSIC), Barcelona, Spain. \\ * Corresponding author. E-mail: flicciar@unict.it
}

\begin{abstract}
Increasing our understanding of the main processes acting in small Mediterranean catchments is essential to planning effective soil and water conservation practices in semi-arid areas. A monitoring program of a Sicilian catchment started in 1996 and ended in 2006. The factors driving the hydrological response for 170 events with runoff generation and 46 with sediment production were specified. The catchment response varied greatly over the year. Rainfall intensity was a poor driver of runoff generation, whereas both the simulations made with the Thornthwaite-Mather water balance model and hydrograph recession analyses, pointed to the chief importance of wet antecedent conditions and soil saturation processes in runoff generation. The influence of rainfall spatial variability was also examined. SSC- $Q$ relationships, classified by following their shapes for all sediment production events, suggested that the principal role of small poorly vegetated hillslope patches was as sediment sources and confirmed the complexity of the hydrological response in this small Mediterranean catchment.
\end{abstract}

Keywords: Hydrological response; Mediterranean hydrology; Runoff generation processes; Flood events.

\section{INTRODUCTION}

In many semi-arid regions, upland areas are of crucial importance as a source of water that is necessary for the human life and activities that are mainly concentrated in the drier downstream areas. The seasonality of the Mediterranean climate means that Mediterranean regions are characterized by unevenly distributed water resources, which mainly depend on runoff generated in mountain areas (Latron et al., 2009; Viviroli and Weingartner, 2004), which are, in addition, highly sensitive to changes in their environment. On the one hand, land cover change may seriously affect the hydrological behaviour of Mediterranean catchments (Licciardello et al., 2017). Vegetation removal following fire increases annual runoff, sediment yields and flood frequency and magnitude, whereas the development and densification of forest cover, often occurring after land abandonment, generally leads to a reduction in annual flows (Nunes et al., 2011). On the other hand, climate change in Mediterranean areas will have a hydrological impact that needs to be assessed and for which water management will have to be adapted (Merheb et al., 2016). Thus, improved understanding of the hydrology of Mediterranean mountain areas may help to anticipate the hydrological consequences of both climate and land cover changes.

In Mediterranean mountain areas, hydrological processes are widely variable in time and space owing to the great variability of rainfall and evapotranspirative demand dynamics. The seasonal dynamics of rainfall and evapotranspiration cause high seasonal variations in soil water content and water table depth, leading to the marked non-linearity of the rainfall-runoff relationship. Examples of this non-linearity of hydrological response have been described in several studies of Mediterranean mountain catchments (Latron et al., 2009). Latron et al. (2008) found that evapotranspirative demand was a factor that introduced most of the non-linearity observed into the monthly rainfall-runoff relationship of the small Cal Rodó catchment. High seasonality was also apparent at the event scale, with a storm-flow coefficient characterized by alternation between wet and dry periods during the year. This seasonal behaviour was also seen in the Ciciriello catchment (Cuomo and Guida, 2016).
Here the authors demonstrated experimentally that this behaviour was due to the existence of a typical hydro-geomorphic threshold system at the event scale, in particular to a steady addition of water from distinct components, each with originally different mechanisms of runoff production and response time.

The complexity of Mediterranean hydrological systems also causes marked variation throughout the year in the dominating runoff generation processes, which change from season to season (Latron and Gallart, 2008; Merheb et al., 2016). This leads to some disagreement among hydrologists on the primary runoff generation mechanism in Mediterranean areas. Some studies (Calvo-Cases et al., 2003; Cantón et al., 2011; Gallart et al., 2008; Martínez-Mena et al., 1998) have argued the traditional perception that the primary runoff generation mechanism is Hortonian overland flow and showed that saturation mechanisms are also relevant, being dominant in subhumid climates.

Small mountainous catchments comprise both hillslopes, where the main sediment sources are located, and river channels, where deposition, riverbed erosion and sediment transfer occur. The interplay between these two compartments is complex and remains largely unknown. In particular, small mountainous Mediterranean catchments are characterized by intermittent river flow coupled with high suspended sediment concentrations transiently reached during events. This leads to great unpredictability and non-linearity of discharge and sediment concentration relations (Soler et al., 2008; García-Rama et al., 2016). In this context, the analysis of this relationship allows not only improved calculation of sediment yield, but may also help in understanding the runoff and sediment production processes active in these catchments.

Better knowledge of these processes is essential for planning effective soil and water conservation practices in semi-arid environments, where accurate runoff and sediment yield predictions are difficult, particularly in the absence of adequate data.

The main objective of this article is to analyse the hydrological factors and processes that control runoff and sediment yield in a small mountainous Mediterranean catchment. To achieve this aim, a monitoring program of a Sicilian catchment started in 1996. More precisely, the present paper aims: 1) to analyse the hydrological response of the small catchment at different 
temporal scales; 2) to explore to what extent runoff is generated by rainfall excess or saturation mechanisms; 3 ) to examine how the various hydrological factors affect the hydrological response of the catchment; 4) to explore discharge and suspended sediment concentrations at the event scale, with a view to establishing the relationships between these two variables.

\section{MATERIAL AND METHODS Study site}

The small Cannata catchment is drained by a mountain stream, ephemeral in flow, tributary of the Flascio River and located in eastern Sicily ( $37^{\circ} 53^{\prime} 5^{\prime \prime}$ N, $14^{\circ} 52^{\prime} 48^{\prime \prime}$ E). Climate is Mediterranean sub-humid with a mean annual precipitation (1996-2005) of $715 \pm 163 \mathrm{~mm}$, mainly falling between October and January. Mean monthly temperature is between $6^{\circ} \mathrm{C}$ (January) and $24^{\circ} \mathrm{C}$ (August). Mean monthly values of Potential Evapotranspiration are between $22.6 \mathrm{~mm}$ (December) and $160.7 \mathrm{~mm}$ (July), whereas the annual total is $1001 \pm 48 \mathrm{~mm}$. The catchment covers about $1.3 \mathrm{~km}^{2}$ between $903 \mathrm{~m}$ and 1,270 $\mathrm{m}$ a.s.l. with an average slope of $21 \%$. The longest pathway is about $2.4 \mathrm{~km}$, with an average slope of approximately $12 \%$. Alluvium in the main drainage net is rather coarse and fraction finer than $2 \mathrm{~mm}$ is scarce ( $<10 \%$ for 11 samples).

The Cannata catchment bedrock belongs entirely to the Monte Soro Flysh unit (lower Cretaceous), which consists of a thrust system lying between the Numidian Flysh at the base and the Argille Scagliose Speriori unit. The latter is represented by a tectonic mélange, within which there are exotic blocks, formed by clayey quartz-arenite alternations very similar to those attributed to the Monte Soro unit, from which they can be distinguished only by geometrical position (ISPRAMBIENTE, 2018).

To characterize the topsoil, eleven field soil samples were taken on the hydrological network and fifty-seven on the hillslopes inside the catchment, in the latter starting from the same point and following three main directions (northeastsouthwest, north-south and northwest-southeast) in a squared scheme with a side length of $200 \mathrm{~m}$ based on the observed variation in the texture samples (Figure 1). The survey identified the dominant $(63 \%)$ soil texture in the catchment as clayloam (USDA classification for fine fraction). The rest of the catchment is characterized as loam $(21 \%)$, loam-sand $(10.5 \%)$, clay $(3.5 \%)$ and loam-sand-clay $(2.0 \%)$. The skeleton is between 2.3 and $36.8 \%$. The soil's saturated hydraulic conductivity (at $10-15 \mathrm{~cm}$ of depth), measured with a Guelph permeameter (model 2800, Eijkelkamp, Giesbeek, The Netherlands), was determined at 0.2 to $17.6 \mathrm{~mm} \mathrm{~h}^{-1}$. Soil profile is characterized by two main layers, the first of which has a dominant loam-sand texture ( $73 \%$ of samples) and the second has a prevalent sandy-loam texture. In about $30 \%$ of the catchment, located in the upper part of the hydrological network, the soil depth is from a few centimetres to 0.3 meters. In the rest of the catchment, the soil depth is up to $0.7 \mathrm{~m}$ with the exception of about $5 \%$ of the catchment where the soil depth reaches $1 \mathrm{~m}$. Some shrinking cracks are visible in bare soil areas during dry spells.

Land use and ground cover modifications were monitored every six months at 24 sites within the catchment, using a $1 \mathrm{~m}^{2}$ grid with $0.4 \mathrm{~m}^{2}$ sub-grids. Land use monitoring highlighted the prevalence of pasture areas (ranging between $87 \%$ and $92 \%$ of the catchment area during the observation period) with different vegetation (up to 15 species) and ground cover. The four dominant soil covers included: (1) high-density herbaceous vegetation (eventually subjected to tillage operations) characterized by Ranunculus bulbosus, Trifolium stellatum, Trifolium repens and Festuca circummediterranea, with a ground cover value in the observation period between $17 \%$ and $86 \%$ (mean of $47 \%$ ); (2) medium-density herbaceous vegetation characterized by Dactylis glomerata, Trifolium repens, Cynosoras cristatus and Hedysaram coronarium, with a ground cover value between $14 \%$ and $67 \%$ (mean of $36 \%$ ); (3) sparse shrubs characterized in the higher layer of vegetation by Crataegus monogyna, Genista aetnensis, Calicotome infesta, Rabus ulmifolium and Pyras communis and in the lower layer by the same species as the high-density herbaceous vegetation, with a ground cover value in the observation period between $30 \%$ and $70 \%$ (mean of $50 \%$ ); and (4) cultivated winter wheat planted at the end of October and harvested at the end of July with a wheat-fallow rotation.

The occurrence of overland flow is revealed by a few shallow gullies scattered in mid- and low-slope positions. Most of these gullies are discontinuous ephemeral forms up to $40 \mathrm{~cm}$ deep, but two larger ones are up to $2 \mathrm{~m}$ deep. None of these gullies is longer than $5 \mathrm{~m}$. Small mass movement features in the form of shallow slumps are scattered in the basin, particularly in the margins of incised stream channels.

In the same area and quite close to the hydrological network, there are some ponds for animal watering (Figure 1).

Additional catchment characteristics and sampling information are reported by Licciardello et al. (2006).

\section{Hydrological measurements}

Air temperature, wind, solar radiation and pan evaporation data were recorded by a weather station located close to the catchment (A in Figure 1) with a time resolution of $1 \mathrm{~h}$. Rainfall data were collected at three locations close to and within the Cannata catchment (A, B and C) at $15 \mathrm{~s}$ intervals. Flow levels were recorded right before the confluence with the Flascio river (D), using a floating hydrometrograph (MECHEL mod. ID 5755) hydraulically connected to a slow strait created by a weir. Potential evapotranspiration (PET) was evaluated by using the equation based on the Penman-Monteith (P-M) method reported by the Food and Agricultural Organization (Allen et al., 1998). The P-M method is the recommended PET method for the region that includes the Cannata catchment. Actual evapotranspiration was evaluated by starting from potential evapotranspiration and taking into account evaporation of rainfall intercepted by the plant canopy as well as amounts of transpiration and sublimation/soil evaporation. This was based on an approach similar to that of Ritchie (1972), described in detail in Neitsch et al. (2002).

Suspended sediment concentration was measured by drying filtered stream samples in the oven at $105^{\circ} \mathrm{C}$ for at least 48 hours. Stream water was obtained by an automated water sampler (MODUS mod. 201) with bottles of $200 \mathrm{cc}$ which samples stream water when discharge is above $0.1 \mathrm{~m}^{3} \mathrm{~s}^{-1}$, with increasing intervals (between 2 and 30 minutes) in the first 90 minutes and with constant intervals (30 minutes) until the sixth hour. Coarse sediment particles (diameter $>2 \mathrm{~mm}$ ) occasionally taken by the sampler from the channel bottom were excluded from the calculation. The bedload transport was measured by topographic measurements upstream from the weir for about $10 \mathrm{~m}$ (measured for groups of events up to June 2004). The database covers a period from October 1996 to March 2006 with some gaps (Figure 1). Due to the gaps, for some purposes SSY had to be estimated for erosive events occurring from October 1996 to March 1997 (observed sediment data started on November 1997, Figure 1) and during December 2002 (2 events occurred in December 2002). 


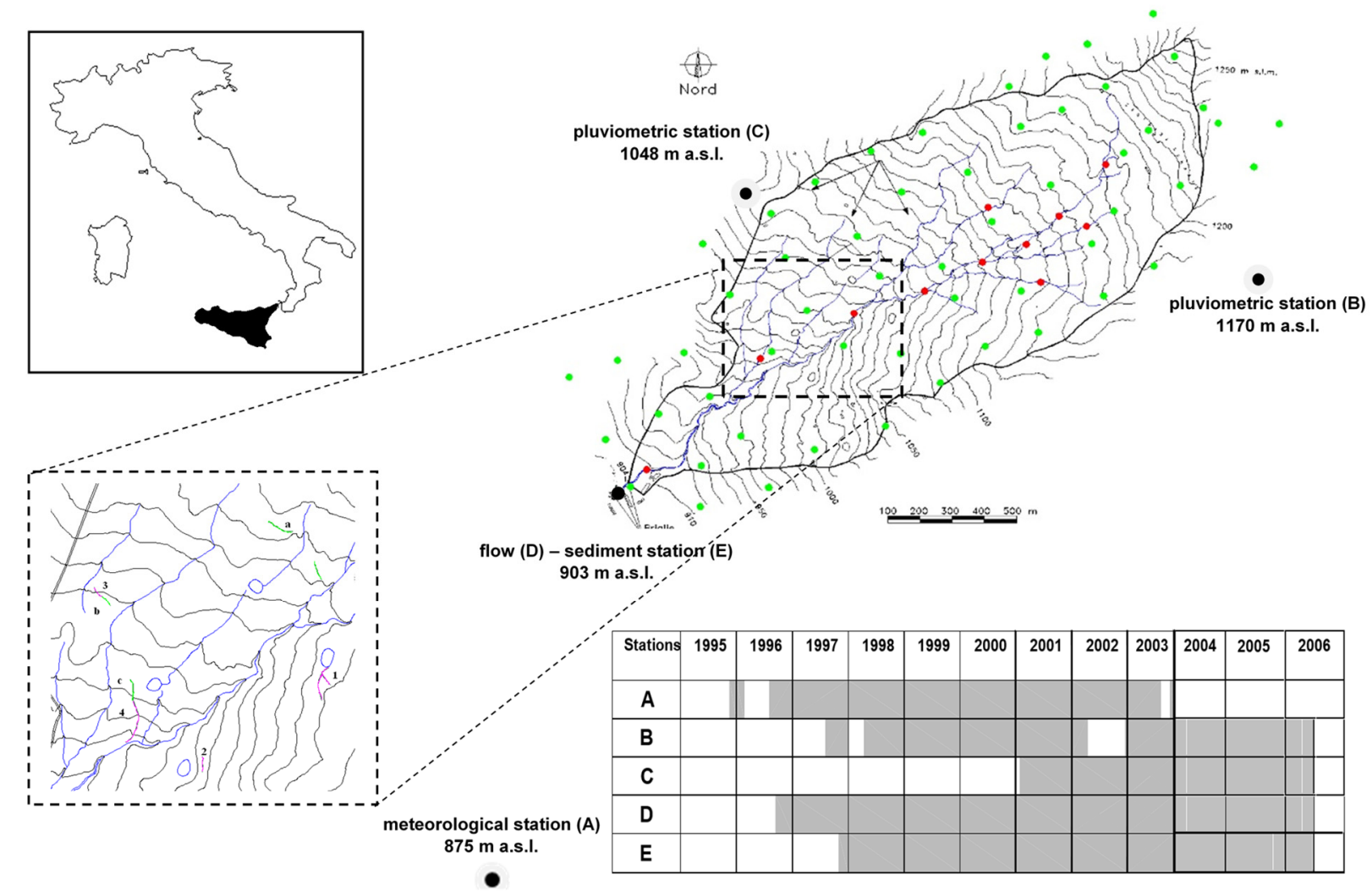

Fig. 1. Layout of sub-watersheds and hydrological network in the Cannata watershed, Sicily. Small dots indicate the location of soil samples. The figure enlargement on the left shows gully formations and small ponds for animal watering. The table shows the recording periods for the diverse stations.

The following abbreviations will be used for the listed variables in the present paper:

$B T$ Bedload transport $(\mathrm{Mg})$

I5 Event maximal rainfall intensity in 5 minutes $\left(\mathrm{mm} \mathrm{h}^{-1}\right)$

I30 Event maximal rainfall intensity in 30 minutes $\left(\mathrm{mm} \mathrm{h}^{-1}\right)$

$N P \quad$ Number of rainy days with depth $>1 \mathrm{~mm}(-)$

$A E T$ Actual evapotranspiration (mm)

$P E T$ Potential evapotranspiration $(\mathrm{mm})$

$P F \quad$ Event peak flow $\left(\mathrm{m}^{3} \mathrm{~s}^{-1}\right)$

$Q \quad$ Discharge $\left(\mathrm{m}^{3} \mathrm{~s}^{-1}\right)$

$P \quad$ Rainfall depth $>1 \mathrm{~mm}(\mathrm{~mm})$

$R C \quad$ Storm runoff coefficient $(\%)$

$R u \quad$ Runoff (mm)

SSC Suspended sediment concentration $\left(\mathrm{g}^{-1}\right)$

SSY Suspended sediment yield $(\mathrm{Mg})$

TS Total sediment yield $(\mathrm{Mg})$

\section{Analysis of hydrological and sediment data}

First, basic statistics, water balance and simple correlation (by using the coefficient of correlation $r$ ) of the variables describing the main characteristics of $P$ and $R u$ depths, $I 30, R C$, $P F, S S Y, S S C$ and $B T$ were analysed at aggregated temporal scales (annual, monthly and mean monthly scale) and the event scale. In particular, monthly and annual maximum values of $I 30$ and $P F$ were the highest values by month and year, respectively. The rest of the monthly and annual data was calculated by adding event data by month and year. Mean monthly data for all considered variables (cumulative or maximum values) were obtained by calculating the averages of monthly data, taking the same month of each year. To analyse the changing behaviour of the catchment throughout the year, basic statistics and simple correlation of the variables were analysed all together and by grouping them in two periods, defining a "wet period" from December to May and a "dry period" from June to November at aggregated and event temporal scales. All the relationships between the main hydrological factors tested were analysed by using the correlation coefficient after the verification of significance. Rainfall variables used in the paper (when it is not specified) are areal averages calculated by the Thiessen polygons method, taking the available measurements for each event.

The patterns and variability of the main rainfall characteristics, depth and intensity, were analysed. In particular, the return period of the $P$ depth and of the $I 30$ was evaluated for all the events by comparing them with the probability curve of the Randazzo meteorological station (located $6.7 \mathrm{~km}$ from the Cannata outlet). The curve was implemented by using the Gumbel distribution (Generalized Extreme Value distribution Type-I). Frequency distributions of $P$ and $R u$ depths, $I 30$ and $S S Y$ at event scale were also analysed. Moreover, the spatial variability of $P$ depth, $I 30$ and $I 5$ among the observations at the three available pluviographic stations was evaluated by calculating the percentage difference between the values recorded for most significant events. Events recorded in the three pluviographic stations were categorized in classes of $5 \mathrm{~mm}$ of depth and $5 \mathrm{~mm} \mathrm{~h}^{-1}$ of intensities and frequencies per each rainfall class were then calculated. In particular, the comparison was carried out for events with $P$ depth greater than $15 \mathrm{~mm}$, then for events with $I 30$ greater than $10 \mathrm{~mm} \mathrm{~h}^{-1}$, and finally for events with $I 5$ greater than $25 \mathrm{~mm} \mathrm{~h}^{-1}$.

Afterwards, when rainfall intensity appeared as a poor driver of runoff response in the catchment, the likely effect of soil saturation on runoff generation was investigated by comparing observed monthly $R u$ depths with saturation excess water calculated with the Thornthwaite-Mather (T-M) water balance model (Steenhuis and Van der Molen, 1986; Thornthwaite and 
Mather, 1955). This conceptual model was selected because it is based in very few assumptions. Precipitation is stored in the soil reservoir until the soil water reaches its maximal value (soil water retention capacity) then the excess water is moved to runoff. The quotient between actual and potential evapotranspiration grows linearly from 0 to 1 following soil water content from 0 to soil water retention capacity, which is the only parameter of the model. The optimisation of this parameter was made using the Nash-Sutcliffe (NS) efficiency criterion (Nash and Sutcliffe, 1970) to test the quality of the simulations. Tutorials of this model can be found on the Internet (https://wwwbrr.cr.usgs.gov/projects/SW_MoWS/Thornthwaite .html). A period consisting of one year with average monthly precipitation and potential evapotranspiration followed by six months of real data was used to warm-up the model, thus obtaining adequate simulated initial soil water content.

A further test to investigate the runoff generation processes was made with the recession limbs of a subset of events without precipitation after the flow peak, for obtaining the recession constants $K$ following the method recommended by Dunne (1978):

$Q_{t}=Q_{0} \cdot K^{t}$

where $Q_{t}$ is discharge at time $t, Q_{0}$ is peak discharge, $K$ is a recession constant and $t$ is the time since the discharge peak (hr). Then the recession constants obtained were analysed for relationships with other hydrological variables and compared with the constants reported by Dunne (1978) for catchments with rainfall excess overland flow, saturation overland flow and subsurface stormflow hydrographs.

Finally, 46 significant events, i.e. those having continuous data and absence of anomalies in the time series, were selected for analysing sediment response varying in time. The data, recorded at different time scales, were used to analyse the relationships between $S S C$ and $Q$ during flood events. The loopshaped curves observed between $S S C$ and $Q$ were used to infer the sediment availability that derives from the sediment source areas and/or from possible intermediate sediment deposits (Williams, 1989). In the clockwise loop, a rapid increase in suspended sediment at the beginning of the flood event is attributed to the presence of available sediment at the water course. If the SSC decreases before the falling limb of the hydrograph, the sediment source areas can be considered limited. In the anticlockwise loop, however, the sediment source areas are mainly located on hillslopes or at headwaters, and/or the sediment moves slower than the peak discharge (Gentile et al., 2010).

\section{RESULTS}

\section{General patterns and water balance}

Over the observation period (October 1996-March 2006), the mean $P$ pattern showed a contrast between summer with a low total amount $(P=91 \mathrm{~mm})$ and the other seasons with a total $P$ amount of $153 \mathrm{~mm}$ (spring), $195 \mathrm{~mm}$ (winter) and 264 (autumn). Sediment yield followed the same trend, being null in summer, $8 \mathrm{Mg}$ in spring, $58 \mathrm{Mg}$ in winter and $97 \mathrm{Mg}$ in autumn. During the same period, mean $R u$ totals had a somewhat different pattern, with winter the most responsive period $(R u=$ $72 \mathrm{~mm})$ followed by autumn $(54 \mathrm{~mm})$, spring $(25 \mathrm{~mm})$ and summer $(R u=0 \mathrm{~mm})$.

Mean monthly data of $P$ and $N P$ measured at the Cannata catchment and long-term monthly mean values of $P$ measured at the Randazzo station were compared (Figure 2). Monthly mean $P$ depths during this 10 -year period were quite representative of the trend observed in the long term ( 48 years) in the area, although $P$ amounts observed in February, July, August and October were underestimated in the 10-year period, and April and December totals were overestimated.

November and December were the months with the highest mean value of $P$, while the highest values of $R u$ depths and $S S Y$ values were in December and January. In particular, during the observation period the seasonal $R u$ in autumn ranged from the minimum $(0 \mathrm{~mm})$ to the maximum $(195 \mathrm{~mm})$ recorded values.

On the annual scale, wide variability in the main hydrological response variables $(R u, R C, P F, S S C, S S Y$ and $B T)$ can be observed (coefficient of variation, $\mathrm{CV}$, between $61 \%$ for $P F$ and $131.5 \%$ for $B T$ ), corresponding to minor variability of $P$, $N P$ and $I 30$ (CV up to $37 \%$ ) (Table 1). The annual $R C$, in particular, varied from 5.72 to $40 \%$, while annual SSY ranged from a minimum of 17.6 to $405.9 \mathrm{Mg} \mathrm{ha}^{-1}$. The annual $B T$ in the observation period was of the same order of magnitude as the $S S Y$; the statistical parameters calculated at the annual scale between the two variables were also very similar (Table 1).

The best results of the T-M water balance model (Figure 3) were obtained by calibration when a soil water-holding capacity of $224 \mathrm{~mm}$ was used. Runoff was simulated as soil saturation excess when this capacity was reached, resulting in good discrimination of the periods with and without runoff $(70 \%)$, although the best NS efficiency was only 0.14 . The analysis of the results showed that this poor efficiency was due to the temporal shifts of two of the months with relevant runoff, November 1996 and December 2002, attributable to the limitations of the monthly temporal scale. Indeed, on shifting backwards one month the $R u$ simulated for these two months, NS efficiency rose to 0.57 and runoff period discrimination to $99 \%$. Despite some limitations, the monthly temporal scale was adequate for describing the variation in water balance over the year in the Cannata catchment. In particular, the seasonal dynamics of both $P$ and PET promote different periods during the year (Figure 2). A dry period occurs during late spring and summer, when low precipitation and high evapotranspiration losses deplete soil water to the point that the $A E T$ to PET ratio may be lower than $20 \%$. Under these conditions most of the rainfall re-evaporates and only long or repeated events are able to generate runoff. A transition period occurs in autumn, as rainfall needs to fill catchment water reserves before runoff is generated. After the filling of water reserves, the wet period usually occurs up to early spring.

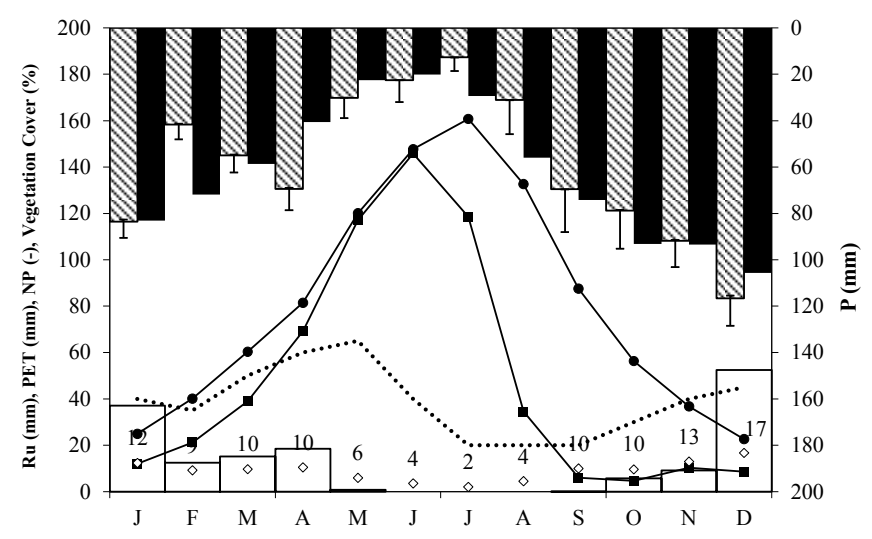

Fig. 2. Monthly mean values of precipitation depths $(P$ and its standard deviation), number of rainy days $(N R a)$, potential evapotranspiration $(P E T)$, actual evapotranspiration $(A E T)$, runoff depths $(R u)$ and Vegetation Cover observed at the Cannata watershed (1996-2006) and long term monthly mean $P$ measured at the Randazzo pluviometric station. 
Hydrological and erosional response of a small catchment in Sicily

Table 1. Summary of annual hydrological records at the Cannata watershed. CV: coefficient of variation, Stdev: standard deviation. *1996 is an incomplete year.

\begin{tabular}{|c|c|c|c|c|c|c|c|c|c|}
\hline $\begin{array}{l}\text { Year/ } \\
\text { Statistics }\end{array}$ & $\begin{array}{l}\text { Precipitation } \\
\text { Depth } \\
(P) \\
\text { mm }\end{array}$ & $\begin{array}{l}\text { Rainy days } \\
(N P)\end{array}$ & $\begin{array}{c}\text { Max rain } \\
\text { intensity } \\
(I 30) \\
\mathrm{mm} \mathrm{h}^{-1}\end{array}$ & $\begin{array}{c}\text { Runoff } \\
\text { depth } \\
(R u) \\
\text { mm }\end{array}$ & $\begin{array}{c}\text { Runoff } \\
\text { coefficient } \\
(R C) \\
\% \\
\end{array}$ & $\begin{array}{l}\text { Peak flow } \\
\qquad(P F) \\
\mathrm{m}^{3} \mathrm{~s}^{-1}\end{array}$ & $\begin{array}{l}\text { Susp. sed. } \\
\text { conc. } \\
(S S C) \\
\mathrm{g}^{-1}\end{array}$ & $\begin{array}{l}\text { Susp. sed. } \\
\text { yield } \\
(S S Y) \\
\mathrm{Mg}\end{array}$ & $\begin{array}{c}\text { Bedload } \\
\text { transport } \\
(B T) \\
\mathrm{Mg}\end{array}$ \\
\hline $1996^{*}$ & 646.6 & 74.0 & 51.8 & 134.6 & 20.8 & 2.4 & 2.1 & 286.2 & 136.7 \\
\hline 1997 & 730.4 & 135.0 & 28.8 & 62.3 & 8.5 & 1.0 & 0.9 & 56.8 & 29.0 \\
\hline 1998 & 537.0 & 118.0 & 21.4 & 30.7 & 5.7 & 0.4 & 0.6 & 17.6 & 68.4 \\
\hline 1999 & 523.0 & 113.0 & 29.1 & 104.4 & 20.0 & 1.4 & 0.5 & 50.5 & 12.5 \\
\hline 2000 & 590.2 & 119.0 & 33.0 & 65.5 & 11.1 & 1.2 & 1.1 & 73.2 & 70.2 \\
\hline 2001 & 621.4 & 115.0 & 26.8 & 45.8 & 7.4 & 0.9 & 0.4 & 18.7 & 9.0 \\
\hline 2002 & 757.0 & 109.0 & 38.8 & 73.6 & 9.7 & 1.1 & 0.7 & 48.5 & 85.4 \\
\hline 2003 & 894.8 & 89.0 & 37.6 & 358.1 & 40.0 & 3.4 & 1.1 & 405.9 & 550.8 \\
\hline 2004 & 724.2 & 96.0 & 61.2 & 276.9 & 38.2 & 2.2 & 0.9 & 242.4 & 197.3 \\
\hline 2005 & 685.2 & 70.0 & 20.6 & 213.1 & 31.1 & 3.3 & 1.5 & 313.3 & \\
\hline Median & 665.9 & 111.0 & 31.0 & 89.0 & 15.5 & 1.3 & 0.9 & 65.0 & 70.2 \\
\hline Average & 671.0 & 103.8 & 34.9 & 136.5 & 19.3 & 1.7 & 1.0 & 151.3 & 128.8 \\
\hline Stdev & 112.3 & 21.0 & 13.0 & 110.4 & 13.0 & 1.0 & 0.5 & 144.8 & 169.4 \\
\hline CV\% & 16.7 & 20.2 & 37.3 & 80.9 & 67.7 & 60.6 & 53.5 & 95.7 & 131.5 \\
\hline Min & 523.0 & 70.0 & 20.6 & 30.7 & 5.72 & 0.37 & 0.4 & 17.6 & 9.0 \\
\hline Max & 894.8 & 135.0 & 61.2 & 358.1 & 40.0 & 3.4 & 2.1 & 405.9 & 550.8 \\
\hline
\end{tabular}

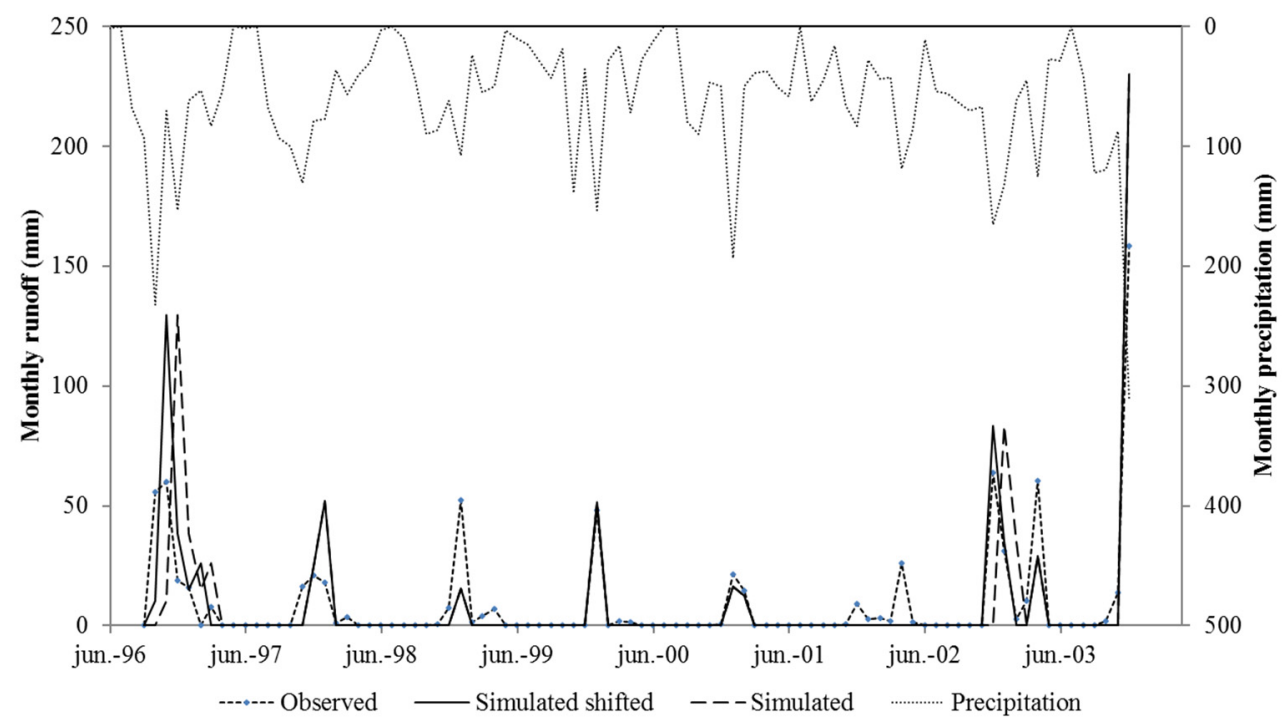

Fig. 3. Monthly precipitation $P$ and runoff $R u$ observed and simulated with the T-M model.

\section{Analysis of the response at the annual and monthly scales}

As well as the soil water balance and T-M model results analysed above, the effects of the main factors driving the response at the Cannata catchment were investigated at different temporal scales by correlations between hydrological variables (Table 2 ).

The correlation between NP and all the selected hydrological response variables was negative and significant at the annual scale, while being positive and always significant at the mean monthly scale. The fact that the correlation was not always significant at the monthly scale was attributed to that the years with few rainfall events generally had a more significant response than those with many events. A clear concentration of major events into a few months was also seen; about $35 \%$ of the total $P$ and $78 \%$ of the total $R u$ was recorded in just $14 \%$ of the 120 months in the study.

Precipitation was a better driver of the Cannata hydrological response in terms of $R u, R C, P F, S S C$ and $S S Y$ than I30. In particular, the correlations $P-R u, P-P F$ and $P-S S Y$ always had significant correlation coefficients equal to or higher than 0.57 at annual, monthly and mean monthly time scales. The fact that I30 was not a good driver of the hydrological response was clearly seen at annual, monthly and mean monthly scales by coefficients of correlation always smaller than 0.51 and frequently non-significant when all the months of the year were taken together (Table 2). Annual $I 30$ explained $70 \%$ of variability on the SSC scale if just the events with runoff higher than 1 $\mathrm{mm}$ were included (data not shown). $R u$ explained somewhat better than $P$ the variability of the sediment response (Table 2) at each analysed temporal scale; in this case, months with zero value of runoff were excluded from the correlation.

The correlation of $T S(S S Y+B T)$ with $P$ and with $R u$ slightly increased with respect to the correlation with the $S S Y(\mathrm{r}=0.75$ and 0.91 respectively) at the annual and mean monthly scales. At the monthly scale the correlation decreased because $T S$ data were collected on a seasonal scale (Table 2).

Given the strong differences in water balance during the year, the correlations were also tested after dividing the year into two periods: the wet period from December to May and the dry period from June to November. After this division, the correlations driven by $P, R u$ and $I 30$ generally improved at the monthly and mean monthly scales.

In particular, the wet period was the one with the strongest $\mathrm{P}-\mathrm{Ru}$ relationship (followed by $P-S S C$ and $P-S S Y$ ), attributable to the soil being already wet and the evapotranspirative demand low during this period (Table 2). 
Table 2. Coefficient of correlation between the main hydrological factors at annual, monthly and mean monthly scales in the Cannata watershed.

\begin{tabular}{|c|c|c|c|c|c|c|c|}
\hline & \multicolumn{7}{|c|}{ Coefficient of correlation, $r^{*}$} \\
\hline & $\begin{array}{l}\text { Annual } \\
(\mathrm{n}=10)\end{array}$ & $\begin{array}{l}\text { Monthly } \\
(\mathrm{n}=112)\end{array}$ & $\begin{array}{l}\text { Monthly wet } \\
\quad(\mathrm{n}=58)\end{array}$ & $\begin{array}{l}\text { Monthly dry } \\
(\mathrm{n}=54)\end{array}$ & $\begin{array}{l}\text { Mean monthly all } \\
\qquad(\mathrm{n}=12)\end{array}$ & $\begin{array}{l}\text { Mean monthly wet } \\
(n=6)\end{array}$ & $\begin{array}{l}\text { Mean monthly dry } \\
(n=6)\end{array}$ \\
\hline$P-R u$ & 0.70 & 0.69 & 0.82 & 0.58 & 0.74 & 0.98 & 0.81 \\
\hline$P-R C$ & 0.55 & 0.36 & 0.33 & 0.49 & 0.62 & 0.83 & 0.81 \\
\hline$P-P F$ & 0.57 & 0.73 & 0.84 & 0.60 & 0.79 & 0.96 & 0.81 \\
\hline$P-S S C$ & 0.23 & 0.66 & 0.72 & 0.58 & 0.64 & 0.95 & 0.63 \\
\hline$P-S S Y$ & 0.63 & 0.69 & 0.78 & 0.60 & 0.77 & 0.93 & 0.72 \\
\hline$P-T S$ & 0.75 & 0.58 & 0.66 & 0.51 & 0.76 & 0.91 & 0.55 \\
\hline$N P-P$ & -0.29 & 0.60 & 0.33 & 0.82 & & & \\
\hline$N P-R u$ & -0.65 & 0.24 & 0.11 & 0.28 & 0.80 & 0.98 & 0.78 \\
\hline$N P-R C$ & -0.70 & 0.25 & 0.04 & 0.29 & 0.75 & 0.89 & 0.78 \\
\hline$N P-P F$ & -0.86 & 0.32 & 0.17 & 0.34 & 0.79 & 0.97 & 0.76 \\
\hline$N P-S S C$ & -0.72 & 0.40 & 0.32 & 0.41 & 0.51 & 0.97 & 0.53 \\
\hline$N P-S S Y$ & -0.84 & $\begin{array}{c}0.23 \\
\left(\mathrm{n}=54^{* *}\right)\end{array}$ & $\begin{array}{c}0.11 \\
\left(\mathrm{n}=46^{* *}\right)\end{array}$ & $\begin{array}{c}0.35 \\
\left(\mathrm{n}=8^{* *}\right)\end{array}$ & 0.75 & 0.93 & 0.63 \\
\hline$R u-R C$ & 0.97 & 0.44 & 0.41 & 0.85 & 0.69 & 0.44 & - \\
\hline$R u-P F$ & 0.88 & 0.87 & 0.90 & 0.75 & 0.99 & 0.99 & - \\
\hline$R u-S S C$ & 0.35 & 0.51 & 0.62 & 0.60 & 0.86 & 0.96 & - \\
\hline$R u-S S Y$ & 0.90 & 0.86 & 0.89 & 0.77 & 0.91 & 0.95 & - \\
\hline$R u-T S$ & 0.91 & 0.81 & 0.83 & 0.72 & 0.91 & 0.95 & \\
\hline$I 30-R u$ & 0.45 & 0.28 & 0.46 & 0.45 & -0.27 & 0.51 & - \\
\hline$I 30-R C$ & 0.48 & -0.20 & -0.12 & 0.06 & -0.67 & -0.47 & - \\
\hline$I 30-P F$ & 0.28 & 0.48 & 0.49 & 0.75 & -0.26 & 0.42 & - \\
\hline I30-SSC & 0.36 & 0.51 & 0.25 & 0.70 & -0.01 & 0.52 & - \\
\hline I30-SSY & 0.40 & 0.50 & 0.50 & 0.85 & 0.03 & 0.65 & - \\
\hline
\end{tabular}

All the correlations are significant at $\mathrm{p}<0.05$, except those shown in italics.

* Months with no observed runoff were not included when $R u$ and $I 30$ were used as independent variables

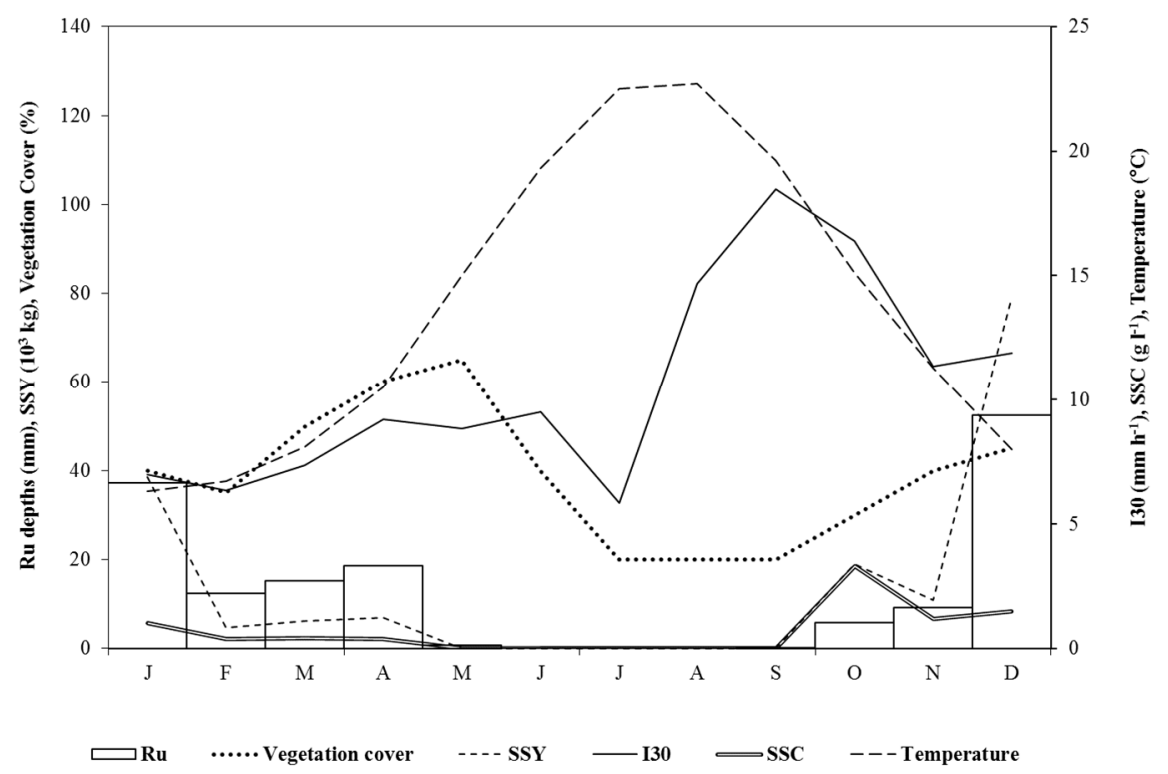

Fig. 4. Mean monthly variation of runoff $(R u)$, vegetation cover, maximal rainfall intensity in $30 \mathrm{~min}$. (I30), suspended sediment yield $(S S Y)$ and suspended sediment concentration $(S S C)$.

After the division of the data into two periods, 130 was a better driver of $P F, S S C$ and $S S Y$ in the dry period than in the wet period. This behaviour was attributed mainly to the relationship between $I 30$ and $R u$ throughout the year (Figure 4). In particular, the highest $I 30$ values were observed from May to October $\left(8.8-16.5 \mathrm{~mm} \mathrm{~h}^{-1}\right)$, when mean monthly $R u$ values were very close to zero, with the exception of October, when mean monthly $S S Y$ actually rose (reaching $18.9 \mathrm{Mg}$ ) and $S S C$ values reached the highest mean monthly value in the year (3.3 $\mathrm{g} \mathrm{l}^{-1}$ ). The values of both SSY and SSC decreased in November, linked to decreased $I 30$ and mean monthly $R u$ depths still being not very high compared with other months.
Then, in December and January we had the highest values of mean monthly $S S Y(79.2$ and $38.6 \mathrm{Mg})$ and high values of $S S C$ (1.0 and $1.5 \mathrm{~g} \mathrm{l}^{-1}$, respectively) linked to the highest values of mean monthly $R u$ depths observed during these months. February was the month with the lowest values of $R u$ depth and $I 30$ of the wet months, when both SSY and SSC reached a minimum. Starting from this month, vegetation cover might also affect the $S S Y$ and $S S C$ values. In particular, even though I3O increased in March and April, SSY and SSC did not increase a lot $\left(6.3\right.$ and $6.9 \mathrm{Mg}$ for $S S Y$ and $0.40 \mathrm{~g}^{-1}$ for $\left.S S C\right)$ : vegetation cover growth might well reduce the role of more water and energy. 
The greater rise of the correlation coefficients at the mean monthly scale than of those at the monthly scale was significant just for the correlations driven by $N P$; mean monthly scale correlations for the dry period were not evaluated because of few data different from zero (Table 2).

\section{Analysis of the response at the event scale}

As explained above, aggregated temporal scales (annual, monthly and mean monthly) are not sufficient to explain the hydrological behaviour of the Cannata catchment. Therefore, the data were also analysed at the event scale.

There were 170 rainfall events with observed $R u$ higher than $0.03 \mathrm{~mm}$ recorded at the Cannata catchment during the monitoring period; just 23 of these events occurred in the dry period (in October and November) and the rest in the wet period (Table 3). Most events had a $P$ depth below the expected 2-year return period for this location; few events showed a $P$ depth higher than the expected value for the 5-year return period $(03 / 10 / 1996 ; 09 / 10 / 1996 ; 30 / 11 / 1996 ; 05 / 04 / 2003)$; and two events observed on $12 / 12 / 2003$ and $13 / 12 / 2005$ had a $P$ depth higher than the expected value for a 200 -year return period. Most events had an 130 below the expected value for a 2-year return period equal to $35.66 \mathrm{~mm} \mathrm{~h}^{-1}$; few events showed a $I 30$ very close to $(19 / 10 / 2003 ; 12 / 12 / 2003 ; 13 / 12 / 2005)$ or higher $(08 / 10 / 1996$ and $11 / 10 / 1996$ with a value equal to 51.8 and 37.1 $\mathrm{mm} \mathrm{h}^{-1}$ ) than the expected value for a 2 -year return period (expected values for 3 and 5-year return period were 44.34 and $54.0 \mathrm{~mm} \mathrm{~h}^{-1}$ ). The combination of high $P$ and $I 30$ resulted in the highest $S S Y$ observed during the observation period (289 $\mathrm{Mg}$ for $13 / 12 / 2005 ; 281 \mathrm{Mg}$ for $12 / 12 / 2003 ; 157 \mathrm{Mg}$ for $08-$ 09/10/1996).

$P, R u$ and $S S Y$ variables showed skewed distributions, with many more observation of low magnitude especially for $R u$ depth and $S S Y$ and especially in the wet period (Table 3). For these two variables, only a few events had high or very high values.

While the five largest rainfall events represented $18 \%$ of the $P$ accumulated during these ten years, their records represented around $33 \%$ of accumulated $R u$ and $45 \%$ of accumulated $S S Y$.

High spatial variability of the main rainfall characteristics was found (Table 4). $P$ depth, $I 30$ and $I 5$ values were recorded for most significant events at the pluviographic stations in the Cannata catchment. $P$ depth differences, evaluated for events greater than $15 \mathrm{~mm}$, were up to $46 \%$. I30 and $I 5$ differences, evaluated for events greater than 10 and $25 \mathrm{~mm} \mathrm{~h}^{-1}$, respectively, were up to $60 \%$. The events with the highest spatial variability in rainfall depth and intensity occurred during the dry period (in the months from September to November).

At the event scale, correlation coefficients confirmed and even clarified some behaviour already noted at aggregated temporal scales (Table 5). $P$ was a better driver of the overall hydrological response than 130 , which had non-significant relationships with $R C$ for all the periods, making clear the low importance of rainfall excess processes in the generation of

Table 3. Summary of the statistics of the variables at the event scale observed at the Cannata watershed (1996-2006) in wet and dry periods as well as all events together. $R D$ : rainfall duration, $R U D$ : runoff duration, $N$ : sample size, Stdev: standard deviation, $\mathrm{CV}$ : coefficient of variation. The other abbreviations are as in Table 1.

\begin{tabular}{|c|c|c|c|c|c|c|c|c|c|}
\hline Wet period & $\begin{array}{c}P \\
\mathrm{~mm} \\
\end{array}$ & $\begin{array}{c}R D \\
\mathrm{~h} \\
\end{array}$ & $\begin{array}{c}130 \\
\mathrm{~mm} \mathrm{~h}^{-1} \\
\end{array}$ & $\begin{array}{c}R U D \\
\mathrm{H} \\
\end{array}$ & $\begin{array}{c}P F \\
\mathrm{~m}^{3} / \mathrm{s} \\
\end{array}$ & $\begin{array}{r}R u \\
\mathrm{~mm}\end{array}$ & $\begin{array}{c}R C \\
\% \\
\end{array}$ & $\begin{array}{c}S S C \\
\mathrm{~g} / 1\end{array}$ & $\begin{array}{l}S S Y \\
\mathrm{Mg}\end{array}$ \\
\hline $\begin{array}{l}\mathrm{N} \\
\text { events in wet period }\end{array}$ & 146 & 146 & 146 & 146 & 146 & 146 & 146 & 50 & 50 \\
\hline Median & 11.5 & 12.0 & 4.8 & 19.5 & 0.2 & 2.6 & 0.3 & 0.8 & 8.7 \\
\hline Average & 18.0 & 14.2 & 5.4 & 26.6 & 0.4 & 7.8 & 0.4 & 1.1 & 27.2 \\
\hline Stdev & 23.2 & 10.1 & 4.2 & 21.8 & 0.5 & 17.1 & 0.3 & 0.9 & 56.5 \\
\hline CV\% & 128.6 & 70.7 & 77.8 & 81.9 & 136.9 & 220.8 & 72.1 & 85.8 & 207.4 \\
\hline Min & 1.2 & 0.6 & 0.4 & 4.5 & 0.0 & 0.0 & 0.0 & 0.1 & 0.6 \\
\hline $\operatorname{Max}$ & 200.6 & 48.7 & 15.3 & 169.5 & 3.4 & 145.3 & 1.0 & 4.9 & 289.2 \\
\hline Skewness & 4.9 & 0.9 & 2.4 & 3.5 & 3.4 & 5.7 & 0.7 & 1.9 & 4.0 \\
\hline \multirow[t]{2}{*}{ Dry period } & $P$ & $R D$ & 130 & $R U D$ & $P F$ & $R u$ & $R C$ & $S S C$ & $S S Y$ \\
\hline & $\mathrm{mm}$ & $\mathrm{h}$ & $\mathrm{mm} \mathrm{h}^{-1}$ & $\mathrm{H}$ & $\mathrm{m}^{3} / \mathrm{s}$ & $\mathrm{mm}$ & $\%$ & $\mathrm{~g} / 1$ & $\mathrm{Mg}$ \\
\hline $\begin{array}{l}\mathrm{N} \\
\text { events in dry period }\end{array}$ & 23 & 23 & 23 & 23 & 23 & 23 & 23 & 8 & 9 \\
\hline Median & 14.8 & 7.8 & 7.7 & 13.0 & 0.2 & 2.4 & 0.2 & 1.4 & 32.4 \\
\hline Average & 22.5 & 10.3 & 13.0 & 20.4 & 0.5 & 6.4 & 0.2 & 2.7 & 33.1 \\
\hline Stdev & 20.0 & 11.3 & 12.1 & 17.8 & 0.6 & 12.6 & 0.2 & 3.1 & 32.1 \\
\hline CV\% & 89.0 & 109.7 & 93.0 & 87.3 & 117.7 & 195.9 & 94.8 & 112.5 & 97.0 \\
\hline Min & 2.8 & 0.4 & 2.0 & 5.5 & 0.0 & 0.0 & 0.0 & 0.0 & 0.1 \\
\hline $\operatorname{Max}$ & 82.4 & 53.8 & 51.8 & 81.0 & 2.4 & 54.0 & 0.7 & 9.7 & 96.6 \\
\hline Skewness & 1.9 & 2.8 & 2.0 & 2.3 & 1.4 & 3.2 & 1.2 & 1.6 & 0.9 \\
\hline \multirow[t]{2}{*}{ All events } & $P$ & $R D$ & $I 30$ & $R U D$ & $P F$ & $R u$ & $R C$ & $S S C$ & $S S Y$ \\
\hline & $\mathrm{mm}$ & $\mathrm{h}$ & $\mathrm{mm} \mathrm{h}^{-1}$ & $\mathrm{H}$ & $\mathrm{m}^{3} / \mathrm{s}$ & $\mathrm{mm}$ & $\%$ & $\mathrm{~g} / 1$ & $\mathrm{Mg}$ \\
\hline $\begin{array}{l}\mathrm{N} \\
\text { all events }\end{array}$ & 170 & 170 & 170 & 170 & 170 & 170 & 170 & 58 & 59 \\
\hline Median & 12.3 & 11.6 & 4.8 & 19.3 & 0.2 & 2.4 & 29.1 & 0.9 & 8.8 \\
\hline Average & 18.3 & 13.7 & 6.5 & 26.4 & 0.4 & 7.5 & 33.2 & 1.3 & 27.7 \\
\hline Stdev & 22.7 & 10.3 & 6.5 & 22.9 & 0.5 & 16.5 & 25.0 & 1.5 & 53.0 \\
\hline CV\% & 124.2 & 75.0 & 100.7 & 86.7 & 133.8 & 219.0 & 75.4 & 120.6 & 191.0 \\
\hline Min & 1.2 & 0.4 & 0.4 & 4.5 & 0.0 & 0.0 & 0.2 & 0.0 & 0.1 \\
\hline Max & 200.6 & 53.8 & 51.8 & 169.5 & 3.4 & 145.3 & 99.3 & 9.7 & 289.2 \\
\hline Skewness & 4.6 & 1.2 & 3.5 & 3.3 & 3.0 & 5.6 & 0.7 & 3.5 & 4.1 \\
\hline
\end{tabular}


Table 4. Percentage differences between rainfall depths $(P)$, along with 30 and 5-minute intensities (I30 and I5) observed for most significant events at the pluviographic stations in the Cannata watershed (indications of event number and data of the event with the maximum difference in brackets).

\begin{tabular}{|c|c|c|c|}
\hline \multirow{2}{*}{ Stations } & \multicolumn{3}{|c|}{ Relative differences } \\
\hline & $P[$ for values $>15 \mathrm{~mm}]$ & $I 30$ [for values $>10 \mathrm{~mm} \mathrm{~h}^{-1}$ ] & $I 5$ [for values $>25 \mathrm{~mm} \mathrm{~h}^{-1}$ ] \\
\hline A-B & $46 \%(42,28 / 11 / 1999)$ & $60 \%(18,19 / 11 / 1999)$ & $62 \%(25,20 / 08 / 1997)$ \\
\hline $\mathrm{A}-\mathrm{C}$ & $35 \%(22,18 / 11 / 2002)$ & $47 \%(14,21 / 08 / 2001)$ & $47 \%(12,15 / 10 / 2003)$ \\
\hline $\mathrm{B}-\mathrm{C}$ & $46 \%(37,26 / 11 / 2003)$ & $53 \%(17,29 / 09 / 2003)$ & $57 \%(19,01 / 09 / 2001)$ \\
\hline
\end{tabular}

Table 5. Correlation coefficients between the main hydrological factors at the Cannata watershed (1996-2006) at the event scale. Abbreviations as in Table 1. All the correlations except those in italics are significant at least at $\mathrm{p}<0.05$.

\begin{tabular}{|c|c|c|c|}
\hline \multicolumn{4}{|c|}{ Correlation coefficient values at the event scale } \\
\hline & Whole period & Wet period & Dry period \\
\hline$P-R u$ & 0.86 & 0.88 & 0.80 \\
\hline$P-R C$ & 0.26 & 0.26 & 0.43 \\
\hline$P-P F$ & 0.76 & 0.82 & 0.45 \\
\hline$P-S S C$ & 0.14 & 0.31 & -0.07 \\
\hline$P-S S Y$ & 0.90 & 0.92 & 0.60 \\
\hline$R D-P$ & 0.23 & 0.17 & 0.74 \\
\hline$R D-R u$ & 0.23 & 0.14 & 0.86 \\
\hline$R u-R C$ & 0.54 & 0.53 & 0.75 \\
\hline$R u-P F$ & 0.84 & 0.90 & 0.60 \\
\hline$R u-S S C$ & 0.04 & 0.24 & -0.23 \\
\hline$R u-S S Y$ & 0.89 & 0.92 & 0.52 \\
\hline$P F-S S Y$ & 0.91 & 0.93 & 0.89 \\
\hline$P F-R C$ & 0.57 & 0.59 & 0.75 \\
\hline$P F-S S C$ & 0.40 & 0.46 & 0.41 \\
\hline$I 30-R u$ & 0.42 & 0.48 & 0.33 \\
\hline$I 30-R C$ & 0.05 & 0.07 & 0.30 \\
\hline$I 30-P F$ & 0.51 & 0.49 & 0.58 \\
\hline I30-SSC & 0.48 & 0.35 & 0.93 \\
\hline$I 30-S S Y$ & 0.67 & 0.74 & 0.79 \\
\hline
\end{tabular}

runoff. However, I3O was the best driver of SSC and, after the subdivision into two periods, also became the best driver of $P F$ and SSY in the dry period. The improvement of the correlations driven by $I 30$ during the dry period can be explained by the events' wider range in this period, with $I 30$ varying from 2.0 to $51.8 \mathrm{~mm} \mathrm{~h}^{-1}$. Therefore, once runoff is generated in this period, even if it is low, the transported sediment rises. For example, two events observed in October and November 1996 gave SSY equal to 0.15 and $4.1 \mathrm{Mg}$ with $R u$ equal to only 2.0 and $3.0 \mathrm{~mm}$.

Rainfall duration did not drive the hydrological response; the high values of $r$ in the dry period are due to a very long event for this climate (53 hours) observed in November 1996. Apart from this correlation, $r$ was generally higher in the wet than in the dry period with the exception of correlations involving $R C$ and $I 30$.

The values of the recession constants $K$ obtained for 54 events with the Dunne (1978) method had a range between 0.33 and 0.83 with a median of 0.6 . These values of $K$ showed a marginally significant negative correlation with $P F(\mathrm{r}=-0.29$, $\mathrm{p}=0.087$ ), but significant negative relationships with $S S C$ $(\mathrm{r}=-0.70)$ and $I 30(\mathrm{r}=-0.44)$. The negative signs were to be expected because the lower the constant $K$ is, the sharper the recession hydrograph. The four events with the lowest $K$ values occurred in October and November.

\section{$S S C-Q$ dynamics during events}

The relationships between $S S C$ and $Q$ were analysed for all 46 events with $S S Y$ in the Cannata catchment. Four classes of the five identified in the literature (Williams, 1989) were identified. The number of events in each class was different. In particular, most of the events, 25 , revealed a clockwise relationship: the sediment peak arrives at the gauging section before the water-discharge peak and the concentration values on the rising limb of the graph are greater for the same discharge than those on the falling limb. These events were characterized by high values of 130 . Eight out of ten events with the highest observed values of $I 30\left(>8 \mathrm{~mm} \mathrm{~h}^{-1}\right)$ revealed a clockwise relationship. The other two events characterized by high values of $I 30$ revealed a figure-eight loop. The shape of these two intense events may be explained by their occurrence just after events with sediment production, so limiting sediment availability. Of the remaining events, seven revealed an anti-clockwise loop with the water-discharge peak arriving at the gauging section before the sediment peak; nine events were characterized by a figure-eight loop (first an anti-clockwise loop and then clockwise) and two were characterized by a single-line-plus loop (Figure 5). It was not possible to identify a prevalent type of event depending on the wet or dry periods because only 3 events with sediment production occurred in the dry period.

\section{DISCUSSION}

Although the analysis of the results for hydrological factors and processes driving runoff and sediment yield in the Cannata catchment showed some similarities with other small mountainous Mediterranean catchments, it also highlighted some behaviour that in the literature was not usually attributed to this area.

With the sub-division of the Mediterranean region into three areas (Merheb et al., 2016), even if Italy is included in the north-western area, the Cannata catchment shared climate characteristics similar to the eastern and southern areas in terms of annual precipitation, runoff, aridity index and coefficient of runoff. Eastern areas were characterized by the highest variability of hydrological response, while southern areas were characterized by the highest aridity index.

The characteristics of precipitation of this Mediterranean climate and the non-linearity of the rainfall-runoff relationships determined very large inter-annual variability in hydrological response in the Cannata catchment, with $\mathrm{CV}$ equal to $83 \%$, $125 \%$ and $128 \%$ for $R C, R u$ and $T S$, respectively. Similar CV values were found in La Conchuela, a small olive catchment on a vertic soil, by Gómez et al. (2014), corresponding with $P$ characterized by $\mathrm{CV}$ values higher (CV about $40 \%$ for $P$ and mean 130 ) than those observed in the Cannata catchment.

\section{Seasonality}

The large temporal variability of monthly rainfall found in the Cannata catchment is also typical of the Mediterranean area. It was also found in the Chicamo catchment in Spain by Martínez-Mena et al. (1998), where about $50 \%$ of precipitation fell in $14 \%$ of the 36 months of the study. More generally, the $P$ pattern identified here is characteristic of the western Mediterranean, being minimal in summer and maximal in autumnwinter. Monthly $R u$ and SSY followed the pattern of precipitation during the winter-spring season, being delayed in autumn due to the deep water deficit in summer. The succession of three different periods during the year, determined by $A E T$, that 

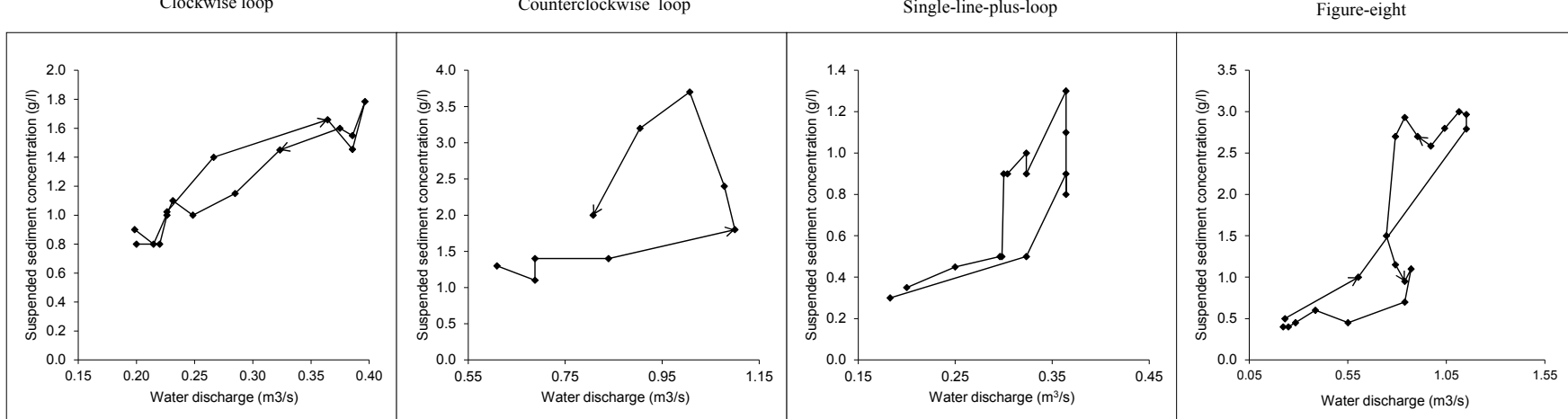

$29 / 12 / 2003$

$14 / 01 / 2000$

$22 / 12 / 1998$

$26 / 11 / 2003$
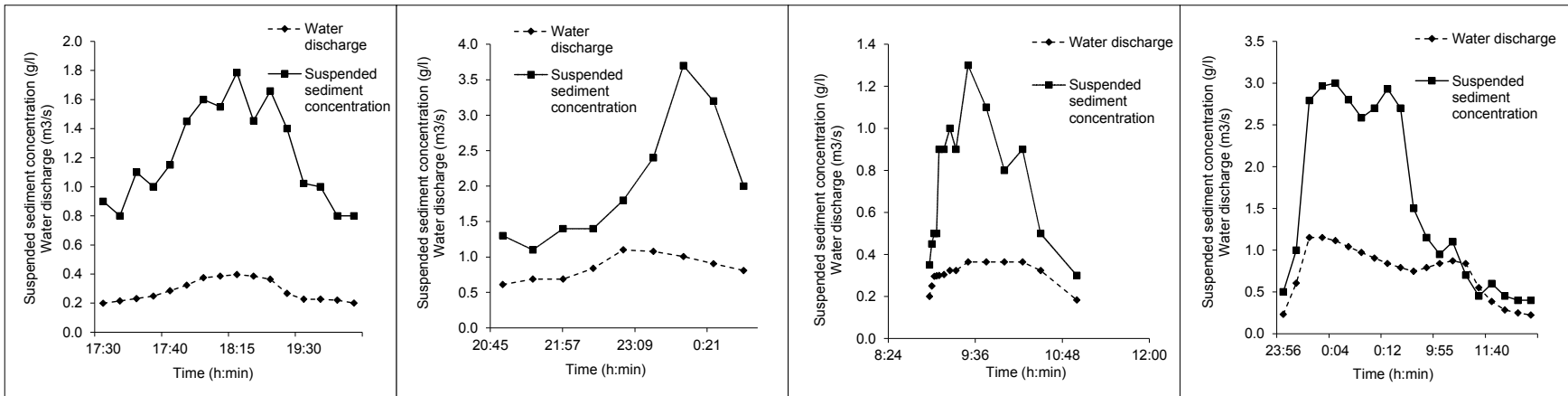

Fig. 5. Examples of suspended sediment concentration - water discharges relationships observed in the Cannata watershed.

were described for the Cannata catchment had already been pointed out by Gallart et al. (2002), Latron et al. (2008) and Estrany et al. (2010) in small mountainous catchments in the western Mediterranean. Predictions of runoff generation in similar catchments should take into account this high variability in soil hydraulics properties (Gómez et al., 2014), which are very difficult to simulate in modelling exercises, especially during the transition period (Licciardello et al., 2007; Taguas et al., 2015).

Runoff coefficient was also very variable between the two semesters of the years; i.e. if we consider two periods with a similar mean $P$ value, i.e. September-November with $73 \mathrm{~mm}$ and February-April with $57 \mathrm{~mm}$, we find an $R C$ of $7 \%$ in the first case and $28 \%$ in the second. Similar differences between $R C$ values in dry and wet periods were found by Latron et al. (2008) and Tuset et al. (2016). These authors suggested the same explanation given for the Cannata catchment: the content of water in the soil before flood events in the wet period is generally higher than in the dry period, conditions that determine the higher $R C$ observed in the former. The month of September with a monthly $P$ in the range $42.4-114 \mathrm{~mm}$ (mean monthly $P$ depth $=69.6 \mathrm{~mm}$ ) always showed $R u$ and $S S Y$ equal to zero. This different behaviour between the two periods is the reason why for all the correlations, especially those driven by $P$ and $R u, \mathrm{r}$ coefficients reached higher values after the division of the data into two periods.

After the division into two periods, $I 30$ was a good driver of the hydrological response in the Cannata catchment only during the dry period and not during the wet period, as generally seen in Mediterranean areas (Martínez-Mena et al., 1998). In the Cannata catchment this behaviour can be explained by the interaction of the vegetation during the wet period and by the fact that runoff and sediment transport were limited despite high $P$ and $I 30$ during the dry period (really during October and November, the only two months without null $R u$ ). Vegetation cover and lithology are the main reasons explaining the lower specific sediment yield found in the Cannata catchment (1.16 $\mathrm{Mg} \mathrm{km}^{-2} \mathrm{y}^{-1}$ ) than in other Mediterranean catchments, along with $S S C$ event values (up to $9.3 \mathrm{~g} / 1$ during October-November before the increase in vegetation). In fact, according to Vanmaercke et al. (2012) the sediment yield of Mediterranean catchments with area $<10 \mathrm{~km}^{2}$ varies between 0.5 and 50,000 $\mathrm{Mg} \mathrm{km}^{-2} \mathrm{y}^{-1}$. Tuset et al. (2016) found an SSC max value of $3 \mathrm{~g} \mathrm{l}^{-1}$, while a total of 5 floods out of 73 reached concentrations exceeding $2 \mathrm{~g}^{-1}$ for a catchment mostly covered by forest. Similarly, in the Cannata catchment this concentration was exceeded by a total of 9 floods out of 46 .

\section{Runoff generation processes}

It is more difficult to explain the hydrological response in the Cannata catchment in terms of either $P$ or $I 30$ for the first events with runoff of each hydrological year. These events were characterized by a mean value of cumulative $P$ from the preceding event with runoff (generally in April or May) of $290 \mathrm{~mm}$. Moreover, the events were characterized by an empirical relative frequency of about $20 \%$ when taking into account the mean values of $P$ depth and $I 30$. This frequency rose to $50-80 \%$ with the mean values of $P F, R u$ and $R C$, and to $70-80 \%$ with the mean values of $S S C$ and $S S Y$. The exceptional event that occurred on 13/12/2005 was excluded from this analysis. These results corroborated those of Gómez et al. (2014) for an olive orchard on a Vertic soil, among others (e. g. Allen et al., 2006).

Even though, at the event scale, I30 improved its driving role of $S S C$ and $S S Y$ (only in the dry period), it remained a weak driver of $P F$ and poor of $R C$. Estrany et al. (2010)'s findings were the same. They explained that the negative correlation between $I 30$ and $P F$ was due to the most intense rainfall occurring in the summer, when the soil water content was low 
and there was no flow into the channel. This meant that maximum $P F$ was lower although rainfall intensities were higher. As stated above, this was also true for the Cannata catchment. Thus, the results in the Cannata catchment contradicted the common opinion that rainfall excess runoff generation process prevails in semi-arid areas. In our case, saturation overland flow seemed to prevail, as confirmed by the lack of significance of correlation coefficients between $I 30$ and $R C$ but also by the success of the T-M water balance model for simulating the main runoff periods observed in the catchment. Gallart et al. (2008) found similar results in a set of Mediterranean headwater catchments characterized by the temporariness of flow. Ries et al. (2017) also found the prevalence of rainfall excess runoff generation process only in arid areas, while in semi-arid area catchments, characterized also by different rainfall intensities, soil water storage and bedrock capacity, excess saturation overland flow prevailed. Bracken et al. (2008) found that floods also seem to be more highly related to the total rainfall occurring in a spell of rain (starting after 12 hours without rain) than to the intensity of a storm, although intense bursts of rain control the nature and timing of the flood hydrograph. Conclusive considerations concerning the importance of rainfall intensity for flood generation are made even more difficult due to the complexity of significant storm rainfall. Reaney et al. (2007) highlighted the importance of the temporal fragmentation of highintensity rainfall to determine the amount of runoff temporal fragmentation of high-intensity rainfall. Storms may have the same amount of high-intensity rainfall, but produce very different amounts of discharge if they are characterized by different degree of high-intensity fragmentation. Consequently, the use of constant intensity during the whole event could lead to incorrect estimations of hydrological response in modelling exercises applied in semi-arid conditions.

The recession constants $K$ obtained for the analysed events also support the prevalence of saturation mechanisms over rainfall excess ones. Indeed, the $K$ values obtained in this study $(0.33$ 0.83 ) are well within the range of those reported by Dunne (1978) for the $0.59 \mathrm{~km}^{2}$ Sleepers River watershed W-2 characterized by saturation (variable source area) mechanisms $(0.42$ 0.81 ), while they are clearly larger (smoother) than those reported by the same author for the $0.83 \mathrm{~km}^{2}$ Stillwater Watershed -4 characterized by rainfall excess overland flow (0.032-0.27).

Moreover, in catchments with prevalent fine texture, the delay of the hydrological response observed during the transition period, which is due to the filling of soil water reserves, may be more marked in the event of crack formations (Gómez et al., 2014). This is a working hypothesis for the case of the Cannata catchment where shrinking cracks were observed during the transition period, in summer and at the beginning of autumn. Afterwards, once the rainy season begins, the soil surface becomes moist, the soils swell and the fine cracks close, reducing infiltration and allowing the generation of overland flow because of rainfall-excess generation mechanisms. Arnold and Fohrer (2005) found that, in Texas, crack volume and PET have similar distributions, but there is about a 3-month lag between peak $A E T$ and peak crack volume. Based on the similarities of $P E T$ and $A E T$ characteristics found by Arnold and Fohrer (2005) and simulated in the Cannata catchment by SWAT (Licciardello et al., 2011), crack volume started to increase in May, reached its maximum in September and decreased between October and November. These months were still part of the dry period that started in May.

It may therefore be argued that the T-M model successfully mimics the periods of high soil wetness, but runoff in these periods may be caused by precipitation over either saturated or crack-sealed ground. In other words, the model success shows the importance of the wet antecedent conditions on runoff generation but not necessarily the operating mechanisms. In the lack of field surveys on the occurrence of saturated areas in the Cannata catchment, the relatively high values of the recession constant $\mathrm{K}$ suggest that runoff is not only due to overland flow, but that there is also some contribution of return flow usually associated with high water-table levels, at least in the riparian area (Dunne, 1978). Periods of high soil-water content in the Cannata catchment are denoted by the occurrence of shallow soil slumps.

The prevalence of saturation overland flow may also be due to the limited soil thickness of the Cannata catchment. Landscape factors such as soil depth (i.e., available water storage capacity), upland watershed area, and local topography are the important factors determining whether or not a particular area in a watershed will generate runoff (Steenhuis et al., 2005). But following the variable source area (VSA) hydrology concept as rainfall continues, the extent of saturated areas in a watershed expands varying temporally. Thus, both hydrologic and soil water (i.e., porous media) concepts are combined to evaluate potential runoff areas in the landscape. In this view, the developing of simple methods to identify the locations more prone to generate runoff could help in the interpretation of the hydrological of small catchments.

\section{Sediment - discharge relationships}

That most events are characterized by a clockwise relationship between $S S C$ and $Q$ is attributable their following a period in which, even if some rainfall occurs, there is no runoff, for example at the beginning of the runoff season or during the early part of a storm. These events are quite intense, so SSC rapidly increases in the rising limb of the hydrograph. This is particular evident for intermittent river, due to the presence of available sediment in the water course (Gentile et al., 2010). In fact, the approaching wave can bring quite a lot of stream bed sediment, that was settled and immobile during no- or low-flow conditions. Then, after reaching the peak, the SSC decreases even if the water discharge is still high, which is attributable to several reasons, such as sediment depletion, the conclusion or decrease in rainfall intensity and the growing contribution of return flow. The prevalence of this kind of relationship may also be because the Cannata stream is quite small (Heidel, 1956). A particular kind of clock-wise loop observed at the Cannata catchment was the single-line-plus-loop. While clockwise, anti-clockwise and mixed loop are well known and very common, not a lot of single-line-plus-loop published (Gentile et al., 2010). These events are characterized by a linear relationship between $S S C$ and $Q$ at the beginning and end of the hydrograph, when the $S S C$ varies directly with discharge. The loop at higher discharge indicates that during the middle of the hydrograph $S S C$ is not in synchronization with $Q$, instead peaking either before or after the discharge. In most cases, the anticlockwise events in the Cannata catchment occurred when the flood started on the falling limb of the previous intense event; with the water discharge peak occurring before the sediment concentration peak because there was still base flow from the previous event. These events occurred only between January and April, never at the start of the runoff season. Mixed loop occurred when there were graded floods, which are characterized by a clockwise relationship at the beginning of the event and an anti-clockwise one afterwards or vice versa.

On the whole event scale, the close correlation coefficients between $P F$ and $S S Y$ found in Cannata are common in small 
catchments elsewhere and attributable to the role of peak flow as a measurement of overall event power (Duvert et al., 2012). $P F$ proved to be the best descriptor of $S S Y$ as found by Duvert et al. (2012) with similar a coefficient and b describing the single power law between the two variables $\left(S S Y=\alpha Q^{\beta}\right)$ for events recorded during the wet period. In particular, $\alpha$ was in the lower part of the identified range 25-5039 $(\alpha=22.9)$ and $\beta$ in the upper part (0.9-1.9) $(\beta=1.9)$. Even lower values for $\alpha$ and higher for $\beta$ were found analysing events recorded during the dry period, supporting the very peculiar response of the Cannata watershed during this conditions.

$S S C$ was also positively related to $I 30$, which is a measurement of event rainfall power, negatively related with the recession constant $K$, which measures recession softness, and quite independent of $R u$, which suggests that neither concentration nor dilution was associated with runoff. Although it has been suggested above that the main runoff generation mechanism is not rainfall excess, the very high correlation coefficient between $I 30$ and SSC during the dry season suggests that sediments are mainly produced in small hillslope source areas of low vegetation cover and poor soil characteristics, such as discontinuous gullies, during intense rainfall events. Even if these events were not sufficient to generate runoff at the catchment outlet, they could carry the sediments to the elementary drainage net, which would permit the occurrence of positive loops in the $S S C-Q$ relationship primarily in the first events of the wet season.

\section{CONCLUSION}

The research reported in this paper provided an analysis of water balance and the main hydrological factors and processes controlling runoff and sediment in a small mountainous Mediterranean catchment. Some similarities and differences with other catchments were highlighted. Seasonal climate forcing in Cannata showed a characteristic Mediterranean pattern with high temporal and spatial variability of precipitation and high concentration of relevant runoff events into a few months. The inter-annual and seasonal variability of the hydrological response of the catchment was even higher than the variability of rainfall, due to the interaction of other factors, among them potential evapotranspiration $(P E T)$, vegetation cover and the role of the soil as a water buffer. Evapotranspiration was the main factor driving the succession of wet, dry and transition periods in the Cannata catchment. The differences in runoff coefficient $(R C)$ values between the different periods were higher than those cited in the literature. Vegetation was also suggested as a factor affecting the response of reduced sediment production in the catchment (as against other catchments in similar environmental conditions). The refining of the analysis divided the data into two periods and, by taking the event scale into account, clarified some behaviour discussed above. For example, rainfall intensity (I30) became a driver for peak flow $(P F)$ and suspended sediment concentration (SSC) during the dry period (really October and November, the only two months of the dry period with runoff) when $I 30$ values were higher than the rest of the year and the vegetation cover was still low. The fact that 130 was generally not a driver of the hydrological response was coherent with the results of the Thornthwaite-Mather soil saturation model simulations. These showed, in contrast with much literature on semi-arid catchments, that runoff generation was dominated by saturation processes in the Cannata watershed. The analysis of the hydrograph recessions suggested rainfall over saturated areas and return flow as the dominant runoff generation processes. The role of soil crack formation and closure in the temporal patterns of runoff was also hypothesized on the basis of their field occurrence, but there is no other evidence to support this. All $S C C-Q$ relationships were positive, with different hysteresis types, but with a prevalence of the clockwise shape, especially at the beginning of the runoff season. This and the clear role of $I 30$ on SSC during the dry season suggest that sediments are mainly produced during intense storms in small hillslope patches with low vegetation cover and poor soil characteristics.

Analysis of results confirmed the complexity and variability of hydrological processes in small Mediterranean catchments. These findings have to be taken into account in land and water management and planning. In particular, they need to be included in modelling exercises at the beginning of the runoff generation season.

Acknowledgements. The research was performed with the Project MASCC (Mediterranean Agricultural Soils Conservation under global Change) funded by Ministero delle politiche agricole, alimentari e forestali, as well as TransHyMed (CGL2016-75957-R AEI/FEDER, UE) and MASCC-DYNAMITE (PCIN-2017-061/AEI) funded by the Spanish Government and the European Union. The authors thank Michael Eaude for English style improvements and two anonymous reviewers for their constructive questions and comments.

\section{REFERENCES}

Allen, R.G., Pereira, L.S., Raes, D., Smith, M., 1998. Crop evapotranspiration: Guidelines for computing crop water requirements. FAO Irrigation and Drainage Paper 56. United Nations FAO, Rome, Italy.

Allen, H.D., Randall, R.E., Amable, G.S., Devereux, B.J., 2006. The impact of changing olive cultivation practices on the ground flora of olive groves in the Messara and Psiloritis regions, Crete, Greece. Land Degradation \& Development, 17, 249-273.

Arnold, J.G., Fohrer, N., 2005. SWAT2000: Current capabilities and research opportunities in applied watershed modelling. Hydrol. Process., 19, 3, 563-572.

Bracken (née Bull), L.J., Cox, N.J., Shannon, J., 2008. The relationship between rainfall inputs and flood generation in south-east Spain. Hydrological Processes, 22, 683-696.

Calvo-Cases, A., Boix-Fayos, C., Imeson, A.C., 2003. Runoff generation, sediment movement and soil water behaviour on calcareous (limestone) slopes of some Mediterranean environments in southeast Spain. Geomorphology, 50, 1-3, 269-291.

Cantón, Y., Solé-Benet, A., De Vente, J., Boix-Fayos, C., CalvoCases, A., Asensio, C., Puigdefábregas, J., 2011. A review of runoff generation and soil erosion across scales in semiarid south-eastern Spain. Journal of Arid Environments, 75, 12, $1254-1261$.

Cuomo, A., Guida, D., 2016. Using hydro-chemograph analyses to reveal runoff generation processes in a Mediterranean catchment. Hydrol. Process., 30, 4462-4476.

Dunne, T., 1978. Field studies of hillslope flow processes. Hillslope Hydrology, 227-293.

Duvert, C., Nord, G., Gratiot, N., Navratil, O., Nadal-Romero, E., Mathys, N., Némery, J., Regüés, D., García-Ruiz, J.M., Gallart, F., Esteves, M., 2012. Towards prediction of suspended sediment yield from peak discharge in small erodible mountainous catchments $\left(0.45-22 \mathrm{~km}^{2}\right)$ of France, Mexico and Spain C. Journal of Hydrology, 454-455, 42-55.

Estrany, J., Garcia, C., Batalla R.J., 2010. Hydrological response of a small Mediterranean agricultural catchment. Journal of Hydrology, 380, 180-190. 
Gallart, F., Llorens, P., Latron, J., Regüés, D., 2002. Hydrological processes and their seasonal controls in a small Mediterranean mountain catchment in the Pyrenees. Hydrology and Earth System Sciences Discussions, European Geosciences Union, 6, 3, 527-537.

Gallart, F., Amaxidis, Y., Botti, P., Canè, G., Castillo, V., Chapman, P., Froebrich, J., García-Pintado, J., Latron, J., Llorens, P., Lo Porto, A Morais, M., Neves, R., Ninov, P., Perrin, J.-L., Ribarova, I., Skoulikidis, N., Tournoud, M.-G., 2008. Investigating hydrological regimes and processes in a set of catchments with temporary waters in Mediterranean Europe. Hydrological Sciences Journal, 53, 3, 618-628.

García-Rama, A., Pagano, S.G., Gentile, F., Lenzi, M.A., 2016. Suspended sediment transport analysis in two Italian instrumented catchments. Journal of Mountain Science, 13, 6, 957-970.

Gentile, F., Bisantino, T., Corbino, R., Milillo, F., Romano, G., Trisorio Liuzzi, G., 2010. Monitoring and analysis of suspended sediment transport dynamics in the Carapelle torrent (Southern Italy). Catena, 80, 1-8.

Gómez, J., Vanwalleghem, T., De Hoces, A., Taguas, E.V., 2014. Hydrological and erosive response of a small catchment under olive cultivation in a vertic soil during a five-year period: Implications for sustainability. Agriculture Ecosystems \& Environment, 188, 229-244.

Heidel, S.G., 1956. The progressive lag of sediment concentration with flood waves. Eos Trans. AGU, 37, 1, 56-66.

ISPRAMBIENTE, 2018. http://www.isprambiente.gov.it accessed on Oct $24^{\text {th }} 2018$.

Latron, J., Gallart, F., 2008. Runoff generation processes in a small Mediterranean research catchment (Vallcebre, Eastern Pyrenees). Journal of Hydrology, 358, 3-4, 206-220.

Latron, J., Soler, M., Llorens, P., Gallart, F., 2008. Spatial and temporal variability of the hydrological response in a small Mediterranean research catchment (Vallcebre, Eastern Pyrenees). Hydrol. Processes, 22, 775-787.

Latron, J., Llorens, P., Gallart, F., 2009. The Hydrology of Mediterranean Mountain Areas. Geography Compass, 3/6, 2045-2064.

Licciardello, F., Amore, E., Nearing, M.A., Zimbone, S.M., 2006. Runoff and Erosion Modelling by WEPP in an Experimental Mediterranean Watershed. In: Owens, P.N., Collins, A.J. (Eds.): Soil Erosion and Sediment Redistribution in River Catchments: Measurement, Modelling and Management. Place. CABI Publisher, Wallingford, Oxfordshire OX10 8DE, UK, pp. 186208.

Licciardello, F., Zema, D.A., Zimbone, S.M., Bingner, R.L., 2007. Runoff and soil erosion evaluation by the AnnAGNPS model in a small Mediterranean watershed. Transactions of the American Society of Agricultural and Biological Engineers (ASABE), 50, 5, 1585-1593.

Licciardello, F., Rossi, C.G., Srinivasan, R., Zimbone, S.M., Barbagallo, S., 2011. Hydrologic evaluation of a Mediterranean watershed using the SWAT Model with Multiple PET Estimation Methods. Transactions of the ASABE, 54, 5, 16151625.

Licciardello, F., Toscano, A., Cirelli, G.L., Consoli, S., Barbagallo, S., 2017. Evaluation of sediment deposition in a Mediterranean reservoir: comparison of long term bathymetric measurements and SWAT estimations. Land Degradation \& Development, 28, 566-578.
Martínez-Mena, M., Albaladejo, J., Castillo, V., 1998. Factors influencing surface runoff generation in a Mediterranean semiarid environment: Chicamo watershed, SE Spain. Hydrol. Processes, 12, 741-754.

Merheb, M., Moussa, R., Abdallah, C., Colin, F., Perrin, C., Baghdadi, N., 2016. Hydrological response characteristics of Mediterranean catchments at different time scales: a metaanalysis. Hydrological Sciences Journal, 61, 14, 2520-2539.

Nash, J.E., Sutcliffe, J.V., 1970. River flow forecasting through conceptual models: 1. A discussion of principles. J. Hydrol., 10, 3, 282-290.

Neitsch, J.G., Arnold, J.G., Kiniry, J.R., Williams, J.R., King, K.W., 2002. Soil and Water Assessment Tool: Theoretical Documentation. Version 2000. TWRI Report TR-191. Texas Water Resources Institute, College Station, TX, USA.

Nunes, A.N., de Almeida, A.C., Coelho, C.O.A., 2011. Impacts of land use and cover type on runoff and soil erosion in a marginal area of Portugal. Applied Geography, 31, 2, 687-699.

Reaney, S.M., Bracken, S.M., Kirkby, M.J., 2007. Use of the Connectvity of Runoff Model (CRUM) to investigate the influence of storm characteristics on runoff generation and connectivity in semi-arid areas. Hydrological Processes, 21, 894-906.

Ries, F., Schmidt, S., Sauter, M., Lange, J., 2017. Controls on runoff generation along a steep climatic gradient in the Eastern Mediterranean. Journal of Hydrology: Regional Studies, 9, $18-33$.

Ritchie, J.T., 1972. Model for predicting evaporation from a row crop with incomplete cover. Water Resour. Res., 8, 1204-1213.

Soler, M., Latron, J., Gallart, F., 2008. Relationships between suspended sediment concentrations and discharge in two small research basins in a mountainous Mediterranean area (Vallcebre, Eastern Pyrenees). Geomorphology, 98, 1, 143-152.

Steenhuis, T.S., Van der Molen, W.H., 1986. The ThornthwaiteMather procedure as a simple engineering method to predict recharge. J. Hydrol., 84, 221-229.

Steenhuis, T.S., Agnew, L., Gérard-Marchant, P., Walter, M.T., 2005. Overland flow. Reference Module in Earth Systems and Environmental Sciences - Encyclopedia of Soils in the Environment, 130-133.

Taguas, E.V., Yuan, Y., Licciardello, F., Gómez, J.A., 2015. Curve Numbers for olive orchard catchments: a case study in Southern Spain. Journal of Irrigation and Drainage Engineering, 141, 11, 05015003/1-05015003/11.

Thornthwaite, C.W., Mather, J.R., 1955. The water balance. Laboratory of Climatology. Report no. 8. Drexel Institute of Technology, New Jersey, USA.

Tuset, J., Vericat, D., Batalla, R.J., 2016. Rainfall, runoff and sediment transport in a Mediterranean mountainous catchment. Science of the Total Environment, 540, 114-132.

Vanmaercke, M., Maetens, W., Poesen, J., Jankauskas, B., Jankauskiene, G., Verstraeten, G., De Vente, J., 2012. A comparison of measured catchment sediment yields with measured and predicted hillslope erosion rates in Europe. J. Soils Sediments, 12, 586-602.

Viviroli, D., Weingartner, R., 2004. The hydrological significance of mountains: from regional to global scale. Hydrology and Earth System Sciences, 8, 1016-1029.

Williams, G.P., 1989. Sediment concentration versus water discharge during single hydrologic events in rivers. Journal of Hydrology, 111, 89-106. 